\title{
The Significance of Double Eagle Represented on Ptolemaic Coins
}

Dalia Amine*, Nagoua Zoair, Wahid Omran

Faculty of Tourism and Hotels, Fayoum University, Egypt:

\section{ARTICLE INFO}

Keywords:

Bronze coins

Co- regency

Ptolemy II

Ptolemy V.

\begin{abstract}
The National Museum of Egyptian Civilization (NEMC) preserved since 2007 a collection of coins that was donated by Emma Jacot to the Greco-Roman Museum of Alexandria in 1953. Some of them were represented with Zeus-Ammon and the double eagles type of with the cornucopia with the epithet ITTOAEMAIO $\Upsilon$ BA $\Sigma \mathbf{E} \Lambda \Omega \Sigma$ have never been published. The scholars have different opinions regarding this type of representation. This research aims to explain the significance of eagle on Ptolemaic coins preserved in NEMC by exanimating and comparing these pieces with other collections with the same representation. The results highlighted some new insights about the eagle and its significance on Ptolemaic coins.
\end{abstract}

(C2021 Faculty of Tourism and Hotels, Fayoum University All rights reserved

\section{Introduction}

After the death of Alexander the Great, Ptolemy I was proclaimed as satrap of Egypt from 323 until 305 B.C. Egypt was like any other Hellenistic province were Hellenised by implementing a Greek currency system. Ptolemy Soter started to elaborate a new monetary system aimed to empower and isolate his realm from the rest of Alexander's territorial states (Manning, 2006, p 7-9).

Precious metals as gold and silver were firstly used to form the coinage system. Alongside, bronze and copper were used as raw materials to form a variety of coins in Alexandria. The first example in Alexandria was figured with the legend of Alexander $\mathrm{A} \Lambda \mathrm{E} \Xi \mathrm{AN} \triangle \mathrm{P}$ wearing the elephant scalp; it was made of bullion with the typical Phoenician standard that so-called Attic Standard. the silver Tetradrachm weighted 17.80 gr. This weight started to decrease gradually to be around 14.25 which is typically Ptolemaic standard (Robert, 1998, 3-4.).

\footnotetext{
*Contact Dalia Amine at: dalia.amine@gmail.com
}

The coins were not only used for economic purpose, but it was a means of political propaganda, indicators of welfare, and religious affiliation. Therefore, the study of the monetary system reveals insights about the economic, social, religious, and political state in any period that the coins belong.

\section{Literature review}

\subsection{Bronze coins}

Milne (1938, p.2003) that the small denomination of the bronze coins was mint Mentions $d$ in the early time of Ptolemaic era as a commemorative portion and later it was used for covering the internal needs such the military salaries and the eternal taxes. Unlike the gold and silver coins, bronze coins were modelled to be used mainly for economic purposes: daily life activities, collecting taxes, soldiers' pay off, and employees' salaries. Despite that, it was decorated with the same 
monograms and religious symbols of other types of coins.

During the Ptolemaic Period, the manufacturing of bronze coins was subject to some reforms. The first reform was taken place by king Ptolemy II Philadelphus (285- 246 B.C). This type of coins was reformed after 266 B.C and expanded to include array of unprecedented large denominations, in different categories. The most important of these, was the types of $42 \mathrm{~mm}$ diameter and 72 grams in weight, with two eagles on the reverse standing on a thunderbolt; the socalled Drachma appeared with the presence of central cavities, and these were struck in both of Syria and Phoenicia. It was so remarkable that Ptolemy II increased the size of all denominations, but he kept the small pieces of the $14 \mathrm{~mm}(1 / 2$ Obol) and $21 \mathrm{~mm}$ (Obol) for the daily needs (Sitta, 2015, p. 63-64). Both silver and bronze were legal tenders to any amount in Egypt. There is no adjustment between the two different materials for the reckoning of the payments, the diffuse of the bronze coins drove out the silver coins from the currency circulation, and the trade of Egypt called for a large supply of the coins with high value. The people obtained the coins with their heavyweight as bigger face value. Comparing the coin weight with Ptolemy Soter, it became six times the largest or the chief bronze coins, and it was taken as drachmas and as result, the amount of the silver coins in the hordes expedition became much less compared to the bronze of the middle of the third century B.C. (Minle, 1938, p. 203-207). The second reform occurred during the reign of Ptolemy Euregetes I in 241. B.C. and it was arranged as the $4^{\text {th }}$ series of coins (Lorber, 2018, p. 82).

\subsection{Double eagle coins}

While the Ptolemaic eagle is a remarkable sign of Ptolemaic royalty and is represented, therefore, on a vast majority of their coins, the double eagle comes in the second rank of the popularity of reverse type (Faucher and Larbor, 2010, p. 36). Both of the two denominations were circulated together. The first appearance of a double eagle on the reverse of bronze coins dates back to the reign of Ptolemy II in 262 B.C. Then it became popular till the end of the Ptolemaic Period.
The reason of its appearance remains undermined; scholars proposed many hypotheses which are subject to acceptance and rejection. The two main hypotheses are:

1. The two eagles indicate denominations.

2. The two eagles indicate the co-regency

The first hypothesis is more accepted by scholars because it refers to the reforming of the old coins, and it is also a way to encourage the users to figure out the difference between the high value and the low-value coins, compared with nowadays coins that have the same size, diameters, and weight but it gives different values, also is it must have been much easier for the taxes collectors to collect money in small amount and bigger value. Richard Pincock (2012) mentions that the two eagles have been considered as indicators of the double value of the coins, so instead of one Obol, it would be diobol. But he found that the single coin represented with one eagle of Ptolemy II and that of the double eagle were minted at the same time with the same weight, size, and value. For that, some scholars rejected the idea of the denomination as there is distinct weight nor size for this type.

The second hypothesis is less accepted by scholars especially during the reign of Ptolemy II. It cannot be considered as the symbol of co-regency. It was not struck during the co-regent time of Ptolemy II with his father Ptolemy I and it appeared around 262 B.C so not even by the end of his reign to show another co-regent period with his son Ptolemy III. It could be valid after that period, during the reign of other Ptolemies such as Ptolemy VI and VIII until Cleopatra VII (50 -30 B.C). The double eagle became an official symbol of the co-regency.

\subsection{The coins of the double eagle in the NEMC collection}

\subsubsection{Coin of Ptolemy II}

Index number: 26237

$\begin{array}{ll}\text { Material: } & \text { Bronze Drachm } \\ \text { Weight: } & 72 \mathrm{gr} \\ \text { Diameter: } & 42 \mathrm{~mm} .\end{array}$

Compared with: Murnane, W, J. (1977). Ancient Egyptian Co-regencies. Studies in Ancient Oriental Civilizations. Chicago Oriental Institute, p.101- the coin. no 2; S.v 705., 711. . 


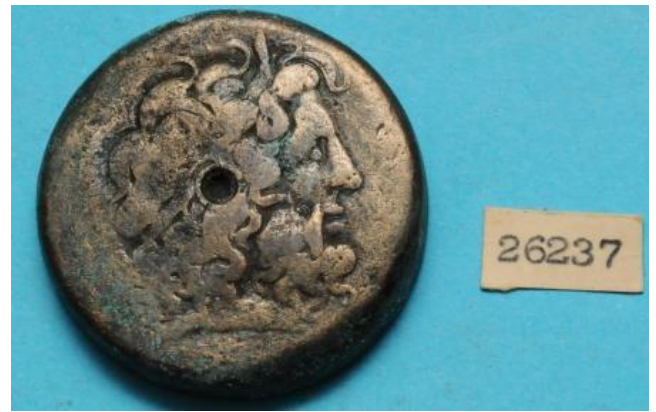

$\mathrm{Ob} /$ head of Zeus Ammon, with a horn of the same god, central cavity, flat border

Rev/ double eagle standing on a thunderbolt bolt with closed wings, dotted border, central cavity, A countermark $\Theta$ the left eagle legs. The legend is just ПTO $А$ EMAIO'Y ........., without other parts

\section{Description}

The obverse shows god Zeus-Ammon with diademed head with tatina tied around the head. The face has big strong features represented in the protruding forehead and deep rounded eye. The nose is also big with the hidden nostril; the mouth lips are fleshy and half-opened; the mustache is a long strip attached to the chin; the beard takes a rounded shape with four curly braids hanging down, the border is flat, the central cavity is very big and deep.

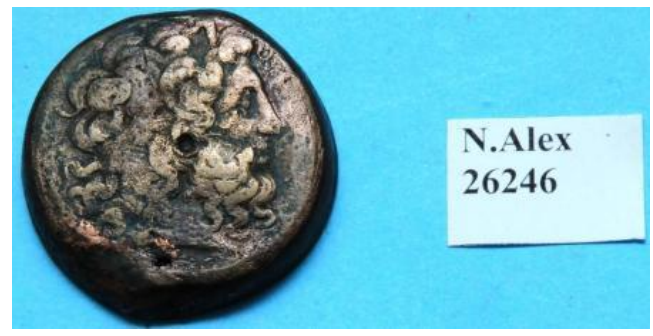

$\mathrm{Ob} /$ diademed head of Zeus-Ammon with a big horn tied with tatina decorated with frontal blossom, central cavity, and flat border.

Rev/ double eagle standing on a thunderbolt closed wings, the two heads converted to the left-field the $\Theta$ monogram is between, little central cavity, flat border. The legend that remains in the left-field as ...MAIOY, the monogram $\Theta$ in between the left eagle's two legs.

Description

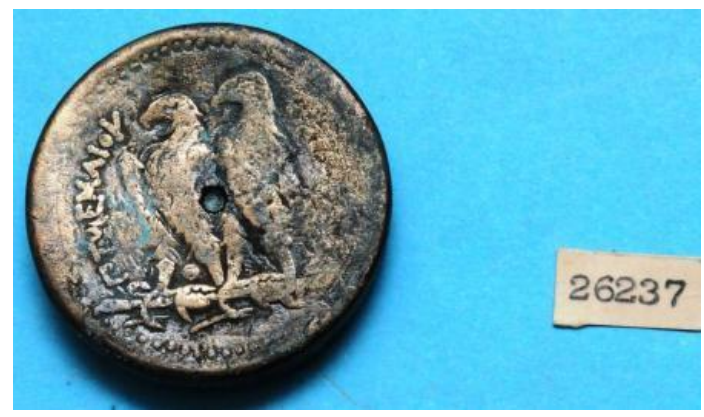

The reverse is represented with two standing eagles on a thunderbolt, with closed wings and their two heads are converted to the left side. The two eagles are slim with no details because of the coin condition, but the right-standing eagle looks taller, the eagles' hooves are very long holding around the thunderbolt, the central cavity is big, the border is dotted.

\subsection{2 coin of Ptolemy II}

Index number: 26246

Material: Bronze Tetrobol

Weight: $70 \mathrm{gr}$

Diameter: $38 \mathrm{~mm}$

Compare with: Labor, C. (2017). Development of the Ptolemaic Bronze coinage., 2017, P1.I, coin. No 8; Larbor C. (2017). Cyrenaica Coinage and Ptolemaic Monetary Policy, 2017, coin, no 4.

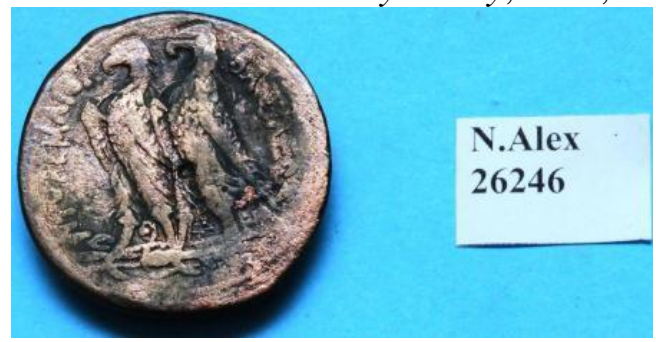

is almost the same as that of the coin number 25237.

\subsubsection{Coin of Ptolemy VI and VII}

Index number 26253

Material Bronze

Weight $31 \mathrm{gr}$.

Diameter $\quad 33 \mathrm{~mm}$

Compared Labor, C, (2017). Development of the Ptolemaic Coins, 2017, P1.5 coin.no.44, Sv. 1904; Sv.1908. no 1423-8 


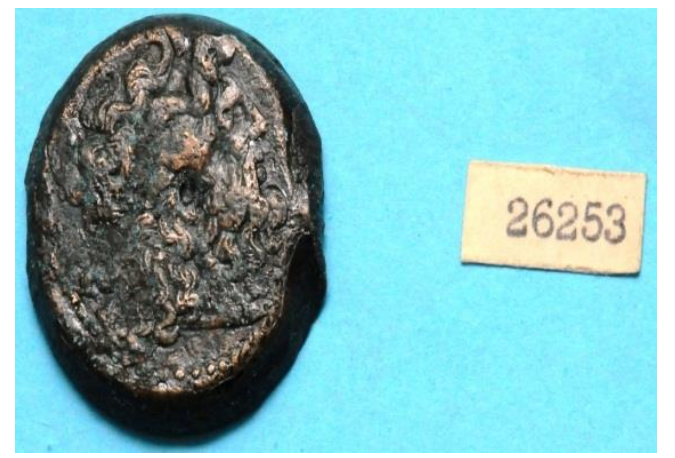

$\mathrm{Ob} /$ diadem head of Zeus - Ammon with a small horn and heavy hair braids.

Rev/ double eagles standing on a thunderbolt, closed wings, the two heads are converted to the leftfield, the cornucopia is in the left-field flat, dotted border. The legend remains ПТО...MAI, $\mathrm{BA} \Sigma \ldots$

\section{Description}

The coin condition is very bad, but the details could be found. The obverse shows the diademed head of Zeus - Ammon who has a different hairstyle from the double eagle coins nos.26237 and 26246, the god face is very small and occupies a tiny space on the right-field although the hair braids are widely spread on the left field.: The hair braids are very long and heavy forming flying in a curly style comes from the forehead to the back direction reaching to the god's shoulder in three long braids, the beard hair is very heavy, curly, and long attached to the head hair above the neck. the facial features are quite calm starting with the little projecting forehead, the eye is small rounded with up looking, the nose is normal. The mustache is long coming down to the chin, the mouth is semiopened, the coin border is flat dotted in the lower part.

The reverse shows a double eagle standing on a thunderbolt, closed wings, the hooves are well and tall, the feathers of the two figures are light and dotted, the double cornucopia is on the left field, the legend remains is flanking the two eagles, the border is dotted.

\section{Discussion and Results}

The NEMC collection of bronze coins includes only 3 coins with double eagles on the reverse type despite its popularity during the Ptolemaic Period. Two of them belong to King Ptolemy II and the third represents the features of coins representing king Ptolemy VI. The three coins have some common features: representation of Zeus- Ammon,

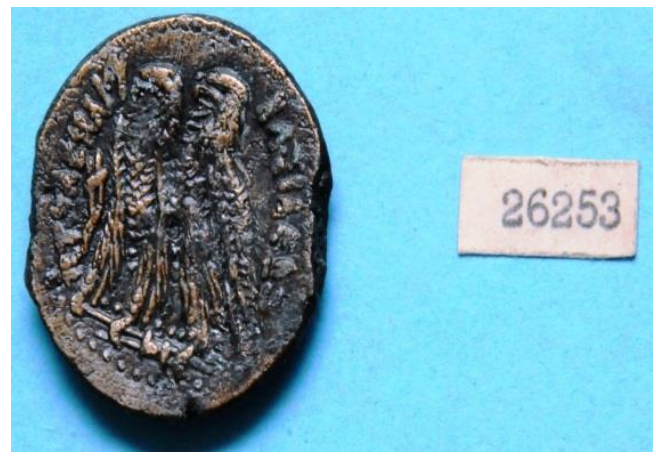

on observe while the double eagles e, two eagles stand on a thunderbolt. However, those of Ptolemy II represents some distinct features such as the central cavity and the sign of $\Theta$ under the left leg. The central cavity appeared for the first time on the above-mentioned example of Ptolemy II. It has no explanation of technical necessity; it refers only to the fabric changes of the new reform circulation (Larbor 2007, p. 117). it was a sign to distinguish between the new denomination and the old one. Bouyon et al. (2000, p. 53-56) suggest

that using pylon - hummer device that was invented It is not possible that this large denomination was struck ed by the Mouseion's scholars as a professional secret of the Alexandria mint, but other examples were minted in the big mint houses in Tyre as well. The absence of a central cavity in the coin of Ptolemy VI confirmed the hypothesis of Larbor.

The two eagles standing on thunderbolt; those of Ptolemy II is standing on a horizontal one while the example of Ptolemy VI standing on a bent one. The latter has also a representation of a cornucopia. some scholars consider it a sign of distinguished denominations that were used as a symbol of the joint reign of Ptolemy VI and VIII (169-163B.C). But the two eagles could also refer to the co-regent of Ptolemy VI and Cleopatra II. The representation of cornucopia is always attached to Ptolemaic queens as a sign of identification with Isis. Mörkholm (1976) points out a chronological significance based on the shape of the eagles' legs on the Ptolemaic coinage by being compared with the bronze coins with silver Tetradrachm of Alexandria after 180; he indicates that the engravers of the third century were always depicted with dotted legs bare of feathers, but under Ptolemy VI the eagle legs were fully feathered down to the claws. 
Therefore, the introduction of these examples shows the feathering eagles' legs as parallel, nearly with horizontal strokes could be included with the Sv.142 B by the first sole reign of Ptolemy VI (176170) B.C. and resumed until 155 B.C. when the Alexandrian mint commenced the dated series of the silver Tetradrachm.

\section{Conclusion}

Based on the opinion of Morkholm that the example of the Ptolemy VI coin dates to the first sole reign of Ptolemy VI and not the period of coregency of the three brothers. Another hypothesis of the representation of the double eagle could be studded. The appearance of a double eagle took place during the reign of Ptolemy II, who started the divinization deification of living Ptolemaic couples when he announced himself and his sister as gods under the name Theoi Adelphois. Then the double eagle became an element that continued to Be used till the end of the Ptolemaic Period.

The concurrence of this new wave deification e of and appearance of the double eagle after the death of Arsinoe could refer to the double eagle as an image of the divine couple. This hypothesis could be an explanation of the continuity of the representation double eagle even in the absence of co-regency. The existence of cornucopia might have strengthened this hypothesis as it is a symbol of both Isis and Ptolemaic queens. Many statues represent them holding this sign as identification with the goddess Isis the study cases were frequently repeated in different studies of different hoard such ( $C H$ 10. 448, P1.17 no. 63, Svoronos, 1904-1908,.nos.1380; SNG. Cop.274-275, and Catharine, L., 2005, P1. 1, 153. Touna el-Gable, 1962., p.371).

\section{References}

Bouyon, B., et al. (2000), Système et Technologie des Monnaie de Bronze (IVe avant J.C.- III 's après J.C.), Wetteren.

Faucher, Th, and Larbor, C. (2010). Bronze Coinage of Ptolemaic Egypt in The Second Centyry B.C. AJN, 22, 35-80.

Larbor, C., (2018). Coins of The Ptolemaic Empire, Ptolemy I Through Ptolemy IV, part. 1, New York.

Larbor, C., (2007). The Ptolemaic Era Coinage Revisited. The Numismatic Chronicle, 167, 105118.

Manning, J. G., (2006). Coinage as 'Code' in Ptolemaic Egypt, SSRN, 2006, 1, 1-41.

Milne, J. G. (1938). The Currency of Egypt under the Ptolemies. Journal of Egyptian Archaeology, 24, 1938, .200-207.

Mörkholm, O. (1976). The Ptolemaic Coins of An Uncertain Era, Stockholm.

Pincock, R. (2012). Are there Denominational Indicators on Ptolemaic Bronze Coins? The numismatic chronicle, 172, 35-46.

Robert, K. R., (1998). Egypt under the Ptolemies: The Legacy of Ancient Egypt, in The Cambridge History of Egypt, 1, 3-13.

Sitta, V, R., Money in Ptolemaic Egypt from the Macedonion Conquest to The End of The Third Century B.C, Cambridge, 2015. 